\title{
Investigation of rheological properties of winter wheat varieties during storage
}

\author{
M. Móré \\ e-mail: morem@agr.unideb.hu \\ G. Diósi \\ e-mail: diosi.gerda@gmail.hu \\ P. Sipos \\ e-mail: siposp@agr.unideb.hu
}

University of Debrecen Centre for Agricultural and Applied Economic Sciences, Institute of Food Science, Quality Assurance and Microbiology,

138 Böszörményi St., H-4032 Debrecen, Hungary

$$
\begin{gathered}
\text { Z. Győri } \\
\text { e-mail: gyori.zoltan@gtk.szie.hu }
\end{gathered}
$$

Szent István University Faculty of Economics and Social Sciences, Institute of Regional Economics and Rural Development, Páter Károly St. 1, H-2103 Gödöllö, Hungary

\begin{abstract}
The paper shows the results of some experimental researches on the rheological characteristics of the dough obtained from the flour of three winter wheat varieties. We used valorigraph test to determine the rheological properties of wheat flour dough, because it determines the quality of the end-products. Winter wheat varieties (Lupus, Mv Toldi and GK Csillag) were produced and their samples were collected on Látókép Research Farm of the University of Debrecen in the crop year of 2011/2012. We have carried out a short-term storage experiment (from July to August, 2012). We analysed the changes in water absorption capacity, dough stability time and valorigraph quality number for 3 times (24.07.2012, 31.07.2012, 21.08.2012) during short-term storage. Our results showed that the baking quality of Lupus, Mv Toldi and GK Csillag improved during the storage period.
\end{abstract}

Keywords and phrases: winter wheat, rheological properties, storage, valorigraph test. 


\section{Introduction}

Wheat is one of the most important bread crops in Hungary. Wheat flour has a unique property, which means if the flour is mixed with water it creates a viscoelastic dough capable of retaining the produced gas during fermentation and at the beginning of baking (Walker and Hazelton, 1996; Khatkar, 2004; Véha et al., 2012).

Storage time has influence on the quality of wheat and milled flour parameters, but it also depends on wheat variety, environmental factors, the conditions of harvest and the milling technology. All the mentioned factors are important for the use of flour and the quality of the end-products (Hrušková and Machová, 2002; Gyimes et al., 2011).

Cereal technologists used traditional dough testing instrument, such as valorigraph, which is an empirical rheological method to predict final product quality (Miranda-Garcia, 2013; Berland and Launay, 1995). The mixing characteristics of wheat dough are largely attributed to gluten proteins. During wheat storage, several biological and chemical interactions occur. Balla et al. (1993) found that a slight growth could be in the quantity of wet gluten content and that the quality of gluten (stability of gluten) improved significantly during after-ripening and storage period also.

Our aim was to determine the changes of rheological properties during the short-term storage of three winter wheat varieties (Lupus, MV Toldi and GK Csillag). We also measured how rheological properties (water absorption capacity, dough stability time and valorigraph quality number) change by the applied different fertilization levels.

\section{Materials and method}

Winter wheat samples were collected from Látókép Research Institute of the University of Debrecen in 2012. The long-term experiment was set up in 1983 and it had a split plot arrangement with three repetitions. Table 1 shows the applied $\mathrm{N} / \mathrm{P}_{2} \mathrm{O}_{5} / \mathrm{K}_{2} \mathrm{O}$ doses in this experiment. We analysed how the valorigraph properties change on the second and fourth NPK treatment levels.

After harvesting and cleaning (MSZ 6367/2:2001), the wheat samples were stored (MSZ 6383:1998) in the sample storage room of the Institute of Food Science, Quality Assurance and Microbiology of the University of Debrecen in polypropylene bags. Three winter wheat varieties were the basis of our study (Lupus, Mv Toldi and GK Csillag), and we examined the wheat samples for three times (24.07.2012, 31.07.2012, 21.08.2012). 
Table 1: The applied NPK doses of the winter wheat field experiment(Látókép)

\begin{tabular}{cccc}
\hline Treatments & $\begin{array}{c}\mathrm{N} \\
(\mathrm{kg} / \mathrm{ha})\end{array}$ & $\begin{array}{c}\mathrm{P}_{2} \mathrm{O}_{5} \\
(\mathrm{~kg} / \mathrm{ha})\end{array}$ & $\begin{array}{c}\mathrm{K}_{2} \mathrm{O} \\
(\mathrm{kg} / \mathrm{ha})\end{array}$ \\
\hline Control & 0 & 0 & 0 \\
1. & 30 & 22.5 & 26.5 \\
2. & 60 & 45 & 53 \\
3. & 90 & 67.5 & 79.5 \\
4. & 120 & 90 & 106 \\
5. & 150 & 112.5 & 132.5 \\
\hline
\end{tabular}

We mixed $1 \mathrm{~kg}$ from each sample and, after homogenization, the wheat conditioning was performed. The moisture content of wheat varies around $14 \%$, depending on the variety, and these will normally need to be conditioned to $16.5 \%$ prior to milling $\left(25^{\circ} \mathrm{C}, 24 \mathrm{hrs}\right)$. Winter wheat samples were milled by a LABOR MIM FQC 109 (METEFÉM, Budapest, Hungary) laboratory mill, and we used a $250-\mu \mathrm{m}$ sieve.

We have carried out a valorigraph test (MSZ ISO 5530-3:1995, METEFÉM FQA 205) to examine the influence of short-term storage on water absorption capacity, dough stability time and valorigraph quality number. The experimental results were analysed by One-Way analysis of variance (Post Hoc test - Duncan test) by the SPSS 13 (statistical programme package (SPSS Inc., USA)) for Windows.

\section{Results and discussion}

The application of $60 / 45 / 53 \mathrm{~kg} / \mathrm{ha} \mathrm{N} / \mathrm{P}_{2} \mathrm{O}_{5} / \mathrm{K}_{2} \mathrm{O}$ doses in a field experiment, water absorption capacity (\%), dough stability time (s) and valorigraph quality number were evaluated three times during the short-term storage (Table 2).

Table 2 shows that the water absorption capacity (\%) and dough stability time (s) did not change significantly within one month after the harvest, but the valorigraph quality number increased during storage time. As the last column of Table 2 shows, quality group increased (from B2 to B1) upon the second time (31.07.2012), but it did not change upon the last measuring time (B1). Significant difference was found in the valorigraph quality number 4 weeks after the first measurement $(21.18 .2012)$. 
Table 2: Influence of short-term storage on the valorigraph parameters of Lupus $\left(60 / 45 / 53 \mathrm{~kg} / \mathrm{ha} \mathrm{N} / \mathrm{P}_{2} \mathrm{O}_{5} / \mathrm{K}_{2} \mathrm{O}\right)$

\begin{tabular}{ccccc}
\hline $\begin{array}{c}\text { Lupus } \\
(60 / 45 / 53)\end{array}$ & $\begin{array}{c}\text { Water } \\
\text { absorption } \\
\text { capacity (\%) }\end{array}$ & $\begin{array}{c}\text { Dough } \\
\text { stability } \\
\text { time (s) }\end{array}$ & $\begin{array}{c}\text { Valorigraph } \\
\text { quality } \\
\text { number }\end{array}$ & $\begin{array}{c}\text { Quality } \\
\text { group }\end{array}$ \\
\hline 24.07 .2012 & $61.4 \pm 0.4^{\mathrm{a}}$ & $620 \pm 17.3^{\mathrm{a}}$ & $54.3 \pm 1.3^{\mathrm{a}}$ & $\mathrm{B} 2$ \\
31.07 .2012 & $61.3 \pm 0.4^{\mathrm{a}}$ & $535 \pm 56.7^{\mathrm{a}}$ & $60.2 \pm 2.4^{\mathrm{a}}$ & $\mathrm{B} 1$ \\
21.08 .2012 & $61.4 \pm 0.3^{\mathrm{a}}$ & $580 \pm 34.6^{\mathrm{a}}$ & $67.7 \pm 5.4^{\mathrm{b}}$ & $\mathrm{B} 1$ \\
\hline
\end{tabular}

Means followed by the same letter within columns were not significantly different according to Duncan's multiple range test $(\mathrm{p} \leq 0.05)$.

Dough stability time (s) and valorigraph quality number changed significantly (Table 3) during storage on a higher fertilization level of Lupus (120/90/106 $\mathrm{kg} / \mathrm{ha} \mathrm{N} / \mathrm{P}_{2} \mathrm{O}_{5} / \mathrm{K}_{2} \mathrm{O}$ ). The water absorption of Lupus was not influenced by the duration of storage.

Table 3: Influence of short-term storage on the valorigraph parameters of Lupus $\left(120 / 90 / 106 \mathrm{~kg} / \mathrm{ha} \mathrm{N} / \mathrm{P}_{2} \mathrm{O}_{5} / \mathrm{K}_{2} \mathrm{O}\right)$

\begin{tabular}{ccccc}
\hline $\begin{array}{c}\text { Lupus } \\
(120 / 90 / 106)\end{array}$ & $\begin{array}{c}\text { Water } \\
\text { absorption } \\
\text { capacity (\%) }\end{array}$ & $\begin{array}{c}\text { Dough } \\
\text { stability } \\
\text { time (s) }\end{array}$ & $\begin{array}{c}\text { Valorigraph } \\
\text { quality } \\
\text { number }\end{array}$ & $\begin{array}{c}\text { Quality } \\
\text { group }\end{array}$ \\
\hline 24.07 .2012 & $63.13 \pm 0.2^{\mathrm{a}}$ & $670 \pm 45.8^{\mathrm{b}}$ & $69.4 \pm 1.1^{\mathrm{b}}$ & $\mathrm{B} 1$ \\
31.07 .2012 & $62.6 \pm 1.0^{\mathrm{a}}$ & $530 \pm 17.3^{\mathrm{a}}$ & $64.7 \pm 2.4^{\mathrm{a}}$ & $\mathrm{B} 1$ \\
21.08 .2012 & $62.87 \pm 0.4^{\mathrm{a}}$ & $655 \pm 8.6^{\mathrm{b}}$ & $69.6 \pm 5.4^{\mathrm{b}}$ & B1 \\
\hline
\end{tabular}

Means followed by the same letter within columns were not significantly different according to Duncan's multiple range test $(\mathrm{p} \leq 0.05)$.

Dough stability time was the highest at the beginning of our evaluations and the strength of dough decreased upon the second time. Dough stability also increased to the last test, but it did not reach the first value. Valorigraph quality number was the lowest on 31.07.2012. Quality group did not change during the short-term storage.

Storage time did not influence the rheological properties of Mv Toldi on the $60 / 45 / 53 \mathrm{~kg} / \mathrm{ha} \mathrm{N} / \mathrm{P}_{2} \mathrm{O}_{5} / \mathrm{K}_{2} \mathrm{O}$ fertilization level (Table 4). Water absorption capacity, stability of dough and valorigraph number showed a slight increase in relation to the advancement of storage time, but it was not statistically significant. 
Table 4: Influence of short-term storage on the valorigraph parameters of MV Toldi $\left(60 / 45 / 53 \mathrm{~kg} /\right.$ ha $\left.\mathrm{N} / \mathrm{P}_{2} \mathrm{O}_{5} / \mathrm{K}_{2} \mathrm{O}\right)$

\begin{tabular}{ccccc}
\hline MV Toldi & $\begin{array}{c}\text { Water } \\
\text { absorption } \\
\text { capacity (\%) }\end{array}$ & $\begin{array}{c}\text { Dough } \\
\text { stability } \\
\text { time (s) }\end{array}$ & $\begin{array}{c}\text { Valorigraph } \\
\text { quality } \\
\text { number }\end{array}$ & $\begin{array}{c}\text { Quality } \\
\text { group }\end{array}$ \\
\hline 24.07 .2012 & $63.2 \pm 3.3^{\mathrm{a}}$ & $480 \pm 51.9^{\mathrm{a}}$ & $60.5 \pm 2.6^{\mathrm{a}}$ & $\mathrm{B} 1$ \\
31.07 .2012 & $64.6 \pm 0.5^{\mathrm{a}}$ & $480 \pm 51.9^{\mathrm{a}}$ & $61.3 \pm 4.1^{\mathrm{a}}$ & $\mathrm{B} 1$ \\
21.08 .2012 & $65.4 \pm 0.3^{\mathrm{a}}$ & $530 \pm 51.9^{\mathrm{a}}$ & $64.9 \pm 3.1^{\mathrm{a}}$ & $\mathrm{B} 1$ \\
\hline
\end{tabular}

Means followed by the same letter within columns were not significantly different according to Duncan's multiple range test $(\mathrm{p} \leq 0.05)$.

Water absorption of MV Toldi was not changed on a higher fertilization level (Table 5). Rheological properties, such as dough strength, valorigraph quality number and quality group, increased significantly to the end of the storage period.

Table 5: Influence of short-term storage on the valorigraph parameters of MV Toldi $\left(120 / 90 / 106 \mathrm{~kg} / \mathrm{ha} \mathrm{N} / \mathrm{P}_{2} \mathrm{O}_{5} / \mathrm{K}_{2} \mathrm{O}\right)$

\begin{tabular}{ccccc}
\hline $\begin{array}{c}\text { MV Toldi } \\
(120 / 90 / 106)\end{array}$ & $\begin{array}{c}\text { Water } \\
\text { absorption } \\
\text { capacity (\%) }\end{array}$ & $\begin{array}{c}\text { Dough } \\
\text { stability } \\
\text { time (s) }\end{array}$ & $\begin{array}{c}\text { Valorigraph } \\
\text { quality } \\
\text { number }\end{array}$ & $\begin{array}{c}\text { Quality } \\
\text { group }\end{array}$ \\
\hline 24.07 .2012 & $65.2 \pm 0.4^{\mathrm{a}}$ & $462 \pm 88.9^{\mathrm{a}}$ & $61.3 \pm 2.7^{\mathrm{a}}$ & $\mathrm{B} 1$ \\
31.07 .2012 & $65.4 \pm 0.2^{\mathrm{a}}$ & $495 \pm 51.9^{\mathrm{a}}$ & $62.3 \pm 2.8^{\mathrm{a}}$ & $\mathrm{B} 1$ \\
21.08 .2012 & $65.6 \pm 0.2^{\mathrm{a}}$ & $670 \pm 73.9^{\mathrm{b}}$ & $74.5 \pm 1.0^{\mathrm{b}}$ & A2 \\
\hline
\end{tabular}

Means followed by the same letter within columns were not significantly different according to Duncan's multiple range test $(\mathrm{p} \leq 0.05)$.

The structure of gluten improved during after-maturing because dough stability time increased significantly. Quality group has also changed (from B1 to A2). In the case of GK Csillag, storage time did not induce significant changes in dough stability, valorigraph quality number and quality group at lower fertilization level (Table 6).

Means followed by the same letter within columns were not significantly different according to Duncan's multiple range test ( $\mathrm{p} \leq 0.05$ ).

Table 7 demonstrates the valorigraph parameters of GK Csillag (120/90/106 $\mathrm{kg} / \mathrm{ha} \mathrm{N} / \mathrm{P}_{2} \mathrm{O}_{5} / \mathrm{K}_{2} \mathrm{O}$ ). In the storage experiment, there were significant differences in dough stability and valorigraph quality number.

At the end of the storage period, these two parameters showed increase; so, the baking quality of GK Csillag improved by higher doses of N/P/K fertilizer. 
Table 6: Influence of short-term storage on the valorigraph parameters of GK Csillag $\left(60 / 45 / 53 \mathrm{~kg} / \mathrm{ha} \mathrm{N} / \mathrm{P}_{2} \mathrm{O}_{5} / \mathrm{K}_{2} \mathrm{O}\right)$

\begin{tabular}{ccccc}
\hline $\begin{array}{c}\text { GK Csillag } \\
(60 / 45 / 53)\end{array}$ & $\begin{array}{c}\text { Water } \\
\text { absorption } \\
\text { capacity (\%) }\end{array}$ & $\begin{array}{c}\text { Dough } \\
\text { stability } \\
\text { time (s) }\end{array}$ & $\begin{array}{c}\text { Valorigraph } \\
\text { quality } \\
\text { number }\end{array}$ & $\begin{array}{c}\text { Quality } \\
\text { group }\end{array}$ \\
\hline 24.07 .2012 & $66.7 \pm 0.8^{\mathrm{a}}$ & $270 \pm 30.0^{\mathrm{a}}$ & $48.5 \pm 4.2^{\mathrm{a}}$ & $\mathrm{B} 2$ \\
31.07 .2012 & $65.4 \pm 0.3^{\mathrm{a}}$ & $300 \pm 0.0^{\mathrm{a}}$ & $47.1 \pm 1.6^{\mathrm{a}}$ & $\mathrm{B} 2$ \\
21.08 .2012 & $65.3 \pm 0.6^{\mathrm{a}}$ & $300 \pm 25.9^{\mathrm{a}}$ & $50.4 \pm 4.0^{\mathrm{a}}$ & B2 \\
\hline
\end{tabular}

Means followed by the same letter within columns were not significantly different according to Duncan's multiple range test $(\mathrm{p} \leq 0.05)$.

Table 7: Influence of short-term storage on the valorigraph parameters of GK Csillag $\left(120 / 90 / 106 \mathrm{~kg} / \mathrm{ha} \mathrm{N} / \mathrm{P}_{2} \mathrm{O}_{5} / \mathrm{K}_{2} \mathrm{O}\right)$

\begin{tabular}{ccccc}
\hline $\begin{array}{c}\text { GK Csillag } \\
(120 / 90 / 106)\end{array}$ & $\begin{array}{c}\text { Water } \\
\text { absorption } \\
\text { capacity }(\%)\end{array}$ & $\begin{array}{c}\text { Dough } \\
\text { stability } \\
\text { time (s) }\end{array}$ & $\begin{array}{c}\text { Valorigraph } \\
\text { quality } \\
\text { number }\end{array}$ & $\begin{array}{c}\text { Quality } \\
\text { group }\end{array}$ \\
\hline 24.07 .2012 & $67.5 \pm 0.4^{\mathrm{a}}$ & $280 \pm 45.8^{\mathrm{a}}$ & $49.7 \pm 3.3^{\mathrm{a}}$ & $\mathrm{B} 2$ \\
31.07 .2012 & $66.2 \pm 0.5^{\mathrm{a}}$ & $335 \pm 31.22^{\mathrm{ab}}$ & $53.3 \pm 3.1^{\mathrm{a}}$ & $\mathrm{B} 2$ \\
21.08 .2012 & $65.6 \pm 1.5^{\mathrm{a}}$ & $375 \pm 39.6^{\mathrm{b}}$ & $62.2 \pm 0.7^{\mathrm{b}}$ & $\mathrm{B} 1$ \\
\hline
\end{tabular}

Means followed by the same letter within columns were not significantly different according to Duncan's multiple range test $(\mathrm{p} \leq 0.05)$.

We analysed the influence of storage time on the valorigraph properties of winter wheat varieties on two $\mathrm{N} / \mathrm{P} / \mathrm{K}$ fertilization levels. In our study, we analysed wheat samples from a lower, $60 / 45 / 53 \mathrm{~kg} / \mathrm{ha} \mathrm{N} / \mathrm{P}_{2} \mathrm{O}_{5} / \mathrm{K}_{2} \mathrm{O}$, and a higher, $120 / 90 / 106 \mathrm{~kg} /$ ha N/ $\mathrm{P}_{2} \mathrm{O}_{5} / \mathrm{K}_{2} \mathrm{O}$, fertilization level. Based on our research, the water absorption capacity of the three winter wheat varieties (Lupus, MV Toldi and GK Csillag) did not change during storage on the applied levels of fertilizer treatments.

Dough stability was not changed on the level of $60 / 45 / 53 \mathrm{~kg} / \mathrm{ha} \mathrm{N} / \mathrm{P}_{2} \mathrm{O}_{5} /$ $\mathrm{K}_{2} \mathrm{O}$ treatment in the case of all the measured wheat varieties, but on the higher level of fertilization $\left(120 / 90 / 106 \mathrm{~kg} / \mathrm{ha} N / \mathrm{P}_{2} \mathrm{O}_{5} / \mathrm{K}_{2} \mathrm{O}\right)$ significant differences were found one month after the harvest as dough stability improved from 31.07.2012 to 21.08.2012 in the case of Lupus, MV Toldi and GK Csillag.

Valorigraph quality number and quality group increased by the end of the storage time by the use of $120 / 90 / 106 \mathrm{~kg} / \mathrm{ha} \mathrm{N} / \mathrm{P}_{2} \mathrm{O}_{5} / \mathrm{K}_{2} \mathrm{O}$ in the case of Mv Toldi, Lupus and GK Csillag. We concluded that the changes in the valorigraph properties of the three wheat varieties were significant in the case of a higher level of fertilization. 


\section{References}

[1] B. S. Khatkar, Rheology and Chemistry of dough. Post-graduated diploma in bakery science and technology. Directorate of Distance Education Guru Jambheshwar University of Science and Technology, (2004) HISAR - 125001.

[2] L. Balla, Z. Bedő, L. Láng, A búza minősége. Gabonaipar, 40. 4. (1993) $1-2$.

[3] S. Berland, B. Launay, Rheological properties of wheat flour doughs in steady and dynamic shear: Effect of water content and some additives, Cereal Chemistry, 72. 1. (1995) 48-52.

[4] E. Gyimes, A. Véha, P. B. Szabó, Effect of short term storage for the wheat quality parameters. In: R. Chibbar \& J. Dexter (eds.), Wheat science dynamics: Challenges and opportunities. Jodhpur Agrobios, (2011) 203-208.

[5] M. Hrušková, D. Machová, Changes of wheat properties during short term storage. Czech J. Food Sci., 20. (2002) 125-130.

[6] O. Miranda-Garcia, The storage of grain and aging of flour, and their effects on flour functionality. An undergraduate thesis submitted to Oregon State University, (2013) 11-13.

[7] C. E. Walker, J. L. Hazelton, Dough rheological testing. Cereal Foods World. 41. (1996) 23-28.

[8] A. Véha, P. B. Szabó, E. Gyimes, PeriTec technology to reduce fusarium toxin in the milling technology. Review of Faculty of Engineering Analecta Technica Szegedinensia, 6. (2012) 131-136. 